\title{
Determinants of E-Learning in Secondary Schools in Kenya: A Case of Selected Public Secondary Schools in Westlands District in Nairobi City County
}

\author{
Francis K. Mutua, Weldon K Ng'eno
}

\begin{abstract}
The report by National Council for Science and Technology (2010) identified that many schools had not started using computers in their classes hence their student missing out ICT benefits like access to educational contents, sharing of information and networking with other students worldwide to share educational materials. The main purpose of the study was to investigate the factors affecting the adoption of elearning in a selected number of public secondary schools in Westlands District in Nairobi City County. The specific objectives of the study included the influence of ICT infrastructure, e-learning curricula and design and teachers readiness on the adoption of e-learning. The study sampled 95 teachers consisting of Head teachers, deputy head teachers and teachers of the selected schools, drawn from target population of 189 using stratified random sampling. The study used a descriptive design in collecting data from the respondents. Data was collected using the questionnaires and analyzed using descriptive statistics with the help of Statistical Package for Social Sciences (SPSS). The study established that schools have low investment in ICT infrastructure due to high cost of computers, software and related accessories, e-learning curricular and lack of teacher readiness as well as minimal capacity of the teachers. The study recommend the need for schools to have e-learning infrastructure included in school budgets stakeholders' e-learning curricula to be customized and for teachers to acquire necessary knowledge and skills that allow them to shift from traditional teaching methods to an elearning style.
\end{abstract}

Keywords: ICT infrastructure, e-learning curricula \& design and teachers readiness

\section{INTRODUCTION}

In describing e- learning Aduke, (2008) notes that it involves the delivery of learning material and lectures using web technologies. This is done in two ways: using only the internet technology or using a combination of internet technology and the traditional face to face teaching or lecturing methodology. Internet technology based delivery involves entirely delivering teaching material without resorting to face to face methodology interaction with the lecturer or teacher. Naidu (2003) observes that e-learning provides students and learners with virtual classroom in contrast with the physical classroom in traditional teaching methodology hence students are able to attend or take their courses using internet technologies from different locations. According to Adam, (2003) E-learning enhances provision of education contents and material through technology at convenient time and place and effectively ensuring achieving the curriculum objectives

In commenting on e-learning uptake in USA, Johnson (2008) indicates that over three million students in USA are now registered in e-learning based academic courses, with an estimated $20 \%$ of the courses being currently offered using internet technologies. Ruth, (2007) acknowledges that many business organizations and public service organizations have taken advantage of e- learning and are currently complementing their traditional training methodologies with e-learning delivered to their employees at their workplaces sand this enables them to save time and cost.

E-learning in Kenya has been adopted and implemented across academic institutions especially in colleges and universities. In fact e-learning has been used in universities as an important component of research support as it facilitates the access and delivery of, online journals and other academic materials. Most of the libraries are networked to enhance student access and coordination among the library staff. Moreover most universities have developed and use academic based software solutions for information management tasks in teaching and researching, student performance data, course evaluations, students' online registration, university management of finance and human resources (RoK, 2007). 
The Kenyan government has promised on realization of quality basic education for all by the year 2015 this is according to policy paper documents (RoK,2010).To achieve the stated goal, the government has adopted the provision of secondary school education using Information and Communication Technology (ICT). The Sessional Paper No. 1 of 2005, KESSP and Vision 2030 also puts more emphasizes on benefits of ICT in education. It explains how ICT aids in laying a base for development of skills and enabling of greater innovations hence making a country achieve a competitive edge (MOE, 2009).

However according to (infoDev; 2007) ICT seems to have penetrated in other sectors more and rapidly than the education sector in Kenya. This includes sectors like communications, banks, medical services and transport. The report by National Council for Science and Technology (2010) identified that many schools had not started using computers in their classes hence their student missing out ICT benefits like access to educational contents, sharing of information and networking with other students worldwide to share educational materials.

Several research has been done to explorer on introduction, use and the potential impact of the ICT) on education especially in the scope of the developed countries hence touching very little on elearning on secondary schools in developing countries (Kastis, 2007). This research study seeks to narrow in to the factors affecting adoption of e-learning in public secondary schools in Kenya.

The main purpose of the study was to explore the factors affecting adoption of e-learning in selected public secondary schools in Westlands District in Nairobi County

The following specific objectives guided the study:

1. Establish the influence of technological infrastructure on the adoption of e-learning in selected public secondary schools in Westlands District in Nairobi County.

2. To investigate the influence of e-learning curricula on the adoption of e-learning in selected public secondary schools in Westlands District in Nairobi County.

3. To examine the effect of teacher readiness on the adoption of e-learning in selected public secondary schools in Westlands District in Nairobi County.

\section{LITERATURE REVIEW}

According to Rogers (2003) diffusion is a process by which innovation conveyed through certain channels in a given period by members of a social system. Surry \& Farquhar (1997) gave the definition as the process by which an innovation is adopted and accepted by members of the community. Growth of individual knowledge and industrial fields resulted to the world to coming up with some of diffusion of innovation models.

There are five characteristics that determine an innovation's adoption rate in a specific social system Rogers (2003).They include relative advantage, compatibility, complexity, trialability, and observability. The degree to which an innovation is perceived be superior than the idea it supersedes is termed as relative advantage. Quick recognition advantages of an innovation leads to faster adoption rate. Compatibility can be defined as the degree to which an innovation is said to be consistent with existing values. Complexity refers to the degree where by innovation's are difficulty to be understood and used. The degree to which an innovation may be experimented with on limited bases can be defined as trialability. Observability refers to the degree to which the results of an innovation can be viewed by others. Quicker positive results of an innovation lead to users adopting it easily (Rogers, 1995).

This theory outlines that the behaviors, beliefs and attitudes of individuals and organizations are strongly influenced by various networks and interactions (Scott, 2001). It also addresses the role of institutions in understanding the behavior of social actors by providing a perspective that helps assess the institutions formal and informal rules. This leads to strong shaping of the beliefs, attitudes and behaviors of social actors (North, 1990; Burkhardt, 1994).

It holds that the institutions' influences on the beliefs, attitudes and behaviors of social actors are secret but insidious. Institutionalization should be better viewed as the 'social process by which individuals came to accept a shared definition of social reality (Scott, 1987).Scott defined institutions as 'social structures that have attained a high degree of resilience' (Scott, 2001). 
The socialization process helps to internalize and encode in to actors. Institutions transform into a particular pattern of attitudes and behaviors, which will shape actors' future attitudes and behaviors and provide stability, order, continuity and meaning to social life. Through their establishment institutions become authoritative guidelines for social behaviors (Scott, 200).So organizational structures and processes inclined in the organization, and become 'taken for granted' as 'the way these things are done' (Scott, 1987). Bythis actors may not even realize that their behaviors are in fact partly shaped by institutions. This theory is related to the variable on e learning curriculum in the research study

The Technology Acceptance Model (TAM) is an information systems theory that models how users come to accept and use a technology. When users are presented with a new technology a number of factors influence their decision about how and when they will use it they include: Perceived usefulness (PU) this was defined by Fred Davis as "the degree to which a person believes that using a particular system would enhance his or her job performance" Perceived ease-of-use (PEOU) this is "the degree to which a person believes that using a particular system would be free from effort" (Davis, 1989).

Technology Acceptance Model states that perceived usefulness and perceived ease of use determine an individual's intention to use a system with intention to use serving as a mediator of actual system use. Perceived usefulness is directly impacted by perceived ease of use. Many researchers have simplified TAM by removing the attitude construct found in TRA (Venkatesh, 2003). TAM has adopted one of three approaches: by introducing factors from related models, by introducing additional or alternative belief factors, and by examining antecedents and moderators of perceived usefulness and ease of use (Wixom and Todd) intention are two widely examined variables in the literature of technology acceptance.

\section{Empirical review}

Schrum and Ohler (2005) argue that distance education "significantly challenges the standard onsite educational culture pedagogically, organizationally, technologically and financially." Flexibility of learning activities: Instructions delivered are independent of time, location, pace and space; hence learners can still face other commitments and learn at their own pace. The increase in enrolment rates in a distance education system lowers the unit cost per learner. Cost effectiveness: permits the achievement of individual educational objectives at affordable costs, without affecting the normal schedule of learners (Olakulehin, 2008).ICT supports personalization, independent learning and teamwork. Students have indicated that they do assignments more their own way when using a computer and their parents consider that they solve assignments more at their own level. Collaboration between students is greater in project work when they use ICT (Balanskat et al., 2006). Ribeiro and Moreira (2009) also add that, a large number of special education professionals agree on the fact that ICTs are an important tool for teachers and students to overcome barriers and promote the acquisition of skills. Furthermore, ICT can promote school and social inclusion by diminishing the obstacles for students with Special Education Needs (Becker, 2000)

Sharma (2003) notes that the use of ICT improves the quality of education by facilitating learning by doing, real time conversation, delayed time conversation, directed instruction, self-learning, problem solving, information seeking and analysis, and critical thinking, as well as the ability to communicate, collaborate and learn (Yuen et al, 2003). Casal (2007) mentions that ICTs also provide a platform for sharing information and knowledge and this can be used for the betterment of program delivery in terms of replication of best practices (Mason, 2000). It allows mass customization in terms of content and exams and reduces costs per student making education more affordable and accessible, increasing enrollments, improving course quality (Ozdemir and Abrevaya, 2007).

It helps to individualize the teaching or guidance method as per the student's need (Mooij, 2007; Ozdemir and Abrevaya, 2007). (Casal, 2007). Mooij (2007) also puts forth the view that ICT facilitates the evaluation and examination of the learning process and results by the students and the parents in a flexible and convenient way (Cross and Adam, 2007). In addition it increased flexibility so that learners can access the education regardless of time and geographical barriers. It enables development of collaborative skills as well as knowledge creation skills; wider availability of best practices and best course material in education, which can be shared by means of ICT. 
Nwagwu and Ahanihe (2006),highlighted factors affecting IT in African as: High cost or even luck of equipments, high cost of software and information by suppliers ; Poor and under developed telecommunication infrastructure, telecommunications barrier due to endless line of regulations and high costs to start one, integration of new ICT developments and knowledge into academic courses and programs remains another major challenge which is affected by the prevailing economic and political environment that may positively or negatively influence ICT adoption in public secondary schools

Low investment in ICT infrastructure coupled with high cost of connectivity and bandwidth are two major problems that the development of ICT infrastructure. Hence one of the barriers to development of ICT in schools is the poor condition of technology infrastructure, in terms of quantity and also quality. Of course this poor condition affects the ease to get access to information. In connection with the availability of infrastructure it makes access to information costly, which in turn makes the use of ICT low. The development of ICTs use in Africa is very uneven. In some countries like South Africa, some sectors of schooling such as management are using computers in education to an extent on par with the developed world, while others are only beginning to explore the possibilities of introducing school networking

Infrastructure for online learning is crucial. Many African countries have a very low base from which to implement ICT interventions in education management in schools. It is estimated that less than 1 per cent of people in Africa uses or have access to the Internet (Bigum, 2000). The figure of 139 students per computer is given for World participants. Listed in order of rank, aspects that inhibit schools from acquiring computers are an absence of electricity, lack of funding, insufficient building space, lack of available and trained staff, and poor security. In Malawi, where most technology infrastructure is government controlled, very low levels of infrastructure for and use of ICTs are found and many government departments have themselves not yet acquired computers. In subSaharan Africa, the low tele-density and high costs of installing and maintaining lines are major barriers. Wireless technology is seen as a possibility for rural schools (for example in Lesotho).

In the ANSTI (2005) report on science and technology status in Africa, the average staff-Computer ratio for Science and Technology faculties in most African universities was found to be about one computer per two staff members. This ratio could be increased by investing more into computer acquisition through a cost sharing model where staffs are assisted to purchase computers through a recovery mechanism. In the same report, it is evident that there is need to improve access to ICT facilities in order to effectively deploy them in institutions of higher learning. The study showed remarkable disparities in the number of computers in each of the 20 universities surveyed from across the African continent On average the analysis showed that there are about 6.5 computers per basic science course and about 9.1 computers per engineering science course. It was also noted that in general, very few departments provide computers to all of their staff. In fact only 1 out of 3 departments across disciplines had more than half of their staff who has computers in their offices.

Most developing countries face capacity constraints, largely a result of thin-bandwidth and frequent power outages (Oyeyinka \& Adeya, 2004). Bandwidth is the scarcest ICT resource in African universities and this is mainly due to vetoes on academic institutions' accessing international circuits and high licensing fees for connecting to advanced circuits for obtaining authorization (Adam, 2003). Adam further reported Jensen's (2002) survey showing that almost $60 \%$ of African countries have bandwidth that is less than that of a typical institution in the developed world and added that only six countries in Africa have a reasonable outgoing bandwidth. Economic factors ranging from the lack of capacity to pay for costly infrastructure to sustaining computer networks introduced through donor funding weighed on the schools as their budgets continued to get slashed. Schools face tough economic factors which includes the lack of ability to pay for costly infrastructure, sustaining computer networks introduced through donor support; all of which is weighed on the education institutions as their budgets continued to get slashed (Adam, 2003).

A comparative study carried out by Angehrn, Nabeth and Roda (2001) shows that many of the existing e-learning systems do not seem to take full advantage of the possibilities offered by current technologies essentially because they are designed to reflect the classic, lecture style teaching approach. Angehrn et al (2001) further add that, e-learning systems should put the user/learner at the centre, and also become a key component for managing individual knowledge capital and competence. According to Webster and Sudweeks (2006), each individual has a learning profile, of which the core constituents are cognitive style, learning style and personality type. 
Abouchedid and Eid (2004) acknowledged that teachers have several concerns related to the transition from traditional education to e-learning. The first concern was that administration officials and instructors were not fully aware of or familiar with e-learning content and outcomes, as well as students' first-time experiences with e-learning courses because of a 180-degree shift in the philosophical learning model. The second concern was that there were not enough plans designed to guide educational institutions for a smooth educational transition to e-learning which can cause unwanted consequences such as a possible drop in students' enrollment leading to a drop in school's revenue. The third concern is that governmental officials refuse the idea of converting educational institutions to - no lecture institutions, indicating that e-learning philosophical models made students independent from their instructors, and the old impression that learning is obtained from the instructor was probably be demolished.

According to Pinheiro (2002), an educational curriculum is - a connective link between teacher and student, organized in such a way to achieve goals previously set by the teacher, the learning organization or by the curriculum specialists. Another definition of curriculum as Todd (1965) stated is - the planned educational experiences offered by a school which can take place anywhere at any time. The curriculum in education guide instructors on how to deliver information to students with respect to the amount of information and the time that this information took to be understood by students. The e-learning curriculum still carries the same definition of Pinheiro, but with extra aspect of e-learning to learn. Learning to learn is an aspect that was found to fulfill the missing component of electronic curriculum; it refers to the capacity of students to learn outside of a paced and structured classroom context (Anderson, 2002).

E-learning course curricula may need to be designed in such a way that is relevant in the quality of information with the outside world because students used different resources besides their instructor. E-learning course curricula may need to be based on learning approaches other than face-to-face course curriculum, which offers students opportunities to discuss their knowledge related to a certain topic rather than only to listen to the instructor as a provider of information. E-learning curriculum could push students to engage in ways not previously possible in face-to-face curriculum, and create new learning and teaching possibilities that generated greater outcomes (DEECD, 2008). According to Colvin and Mayer (2008) an e-learning curriculum may help infuse constructivist learning, when students are encouraged to spend more time interacting with each other than simply listening to the instructor, and requires students to work autonomously and concurrently in a competitive environment so that each individual will construct his or her own knowledge based on the interactions that take place during the e-learning course. The e-learning curriculum is an advanced version of the traditional curriculum, because it focuses more on student-centered learning and effective communication skills to ensure that students and their instructor are involved in a productive sharing of information.

Objective e-learning implementation requires a compatible instructional design that can facilitate the delivery of the e-learning materials, as well as produce desired outcomes that can be noticed on students' performance. Magnussen (2008) observed that instructors need to spend more time on the computer to design an e-learning course. Instructors need to look for suitable ideas that allow them to shift their traditional teaching experiences to an e-learning teaching style. An educator is viewed not as a distributor of content, but as a facilitator of learning (Ruiz, Mintzer, \& Leipzig, 2006).

Teachers may need to acquire knowledge and skills in handling information and communication techniques for e-learning courses. As Levinsen (2007) indicated, that instructors may need to have some form of training in communication skills, because it has a strong effect on e-learning courses. Communication skills play an important role in adapting e-learning skills the instructor has to diversify his communication skills, from beingonly a provider of information to also a facilitator of learning. In order to provide a quality experience in e-learning courses, instructors may need training sessions to improve their skills and online communication. Levinsen (2007) suggested that proper supervision for instructors who are beginning to use an e-learning course will possibly increase instructor skills, while prioritizing instructors 'needs for technical support will speed instructors familiarity with the use of technical tools. Skills, communication, and technology are three related domains that instructors need to adopt to conduct a good quality e-learning course (Georgina \& Hosford, 2009). 
The increasing number of e-learning implementations has resulted in the development of new skills and competencies among faculty members, such as learning how to monitor the learning process without a full control over this process, and how to push discussions forward so that students will cover as much information as they can. Traditional skills are essential to e-learning but are insufficient (Gray, Ryan \& Coulon, 2004). According to Levinsen (2007) successful design and management of e-learning courses require newskills to overcome major problems such as user needs analysis, instructional design, development of materials, delivery of information, and evaluation of the course. The learner needs can be obtained through a questionnaire or survey at the beginning of the course, used to analyze the learner needs to assist the instructor in providing any support needed to make the e-learning course more appealing to learners. A proper instructional design of the course will probably facilitate the learning process to learners. The development of the content may need to be learner-centered rather than instructor-centered, and the content may need to follow the constructivist approach. The delivery of knowledge is dependent on the content; if the content was designed constructively then learners will participate in the delivery process which will possibly increase the amount of knowledge shared among learners as well as the instructor (Gray, Ryan \& Coulon (2004).

In regard to age difference and the implementation of e-learning, Sederberg (2003) indicated that teachers who have been teaching in traditional manners - are not always technologically literate and sometimes resist the innovation of technology and its evolution in education. Teachers are somewhat worried about losing their jobs ife-learning is implemented, because of their inadequate skills with modern technology in education. Sederberg (2003) also showed that technological departments such as those in computer science and learning technologies tend to be more skillful and computer-savvy, indicating a pre-acceptance of e-learning implementation.

Magnussen (2008) indicated that readiness of teachers may include the need to be updated consistently with evolving e-learning issues that could start to appear as e-learning takes place. Barron (2006) mentioned several evaluation tools, one of which is to get learner feedback on e-learning courses by conducting a general survey, which can be reviewed by instructors and school administrators for improvement and suggestions later on. As technology and science advance, the elearning course materials must be updated with the latest information to demonstrate to students that learning content is compatible with the outside world. The success of e-learning is largely dependent on building relationships with learners, with faculty members, and with school administrators during the e-learning process to provide meaningful learning experiences.

\section{Conceptual Framework}

The conceptual framework identifies the variables that when put together explain the issue of concern. The conceptual framework is therefore the set of broad ideas used to explain the relationship between the independent variables (factors) and the dependent variables (outcomes).

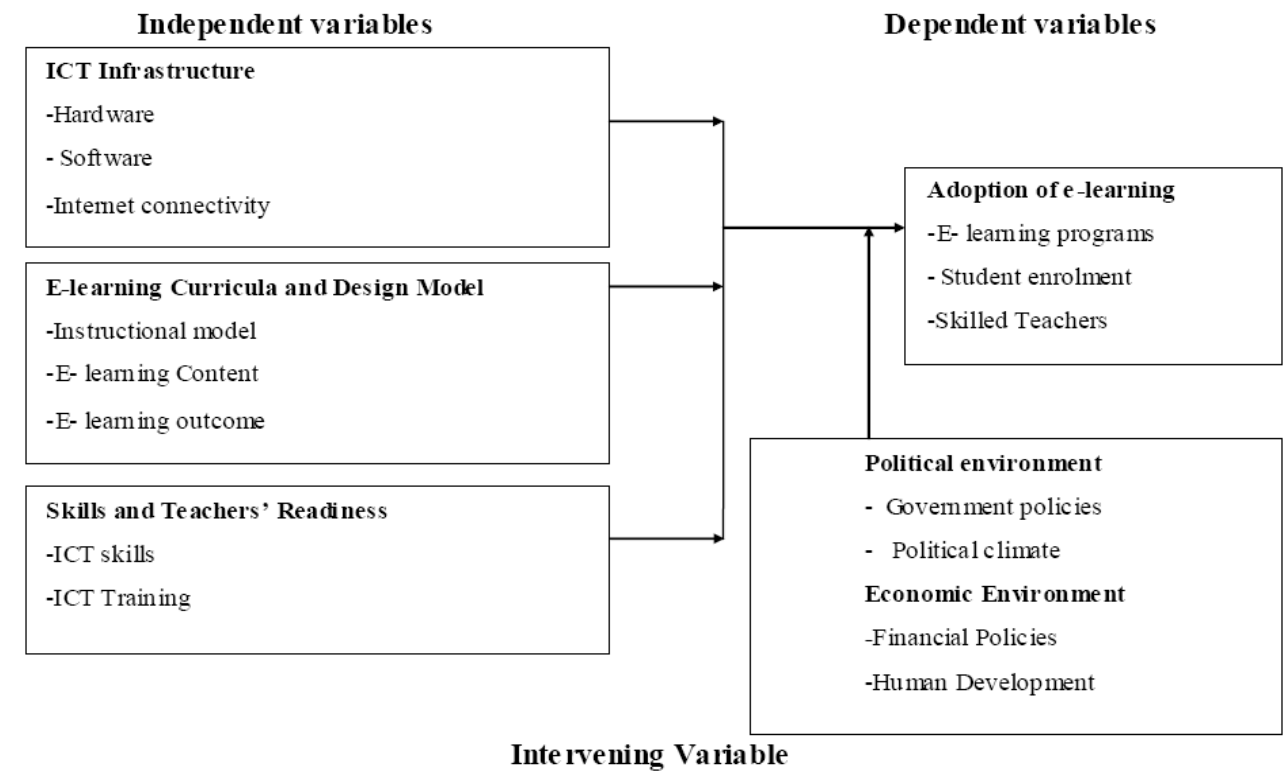

Figure1. Conceptual Framework 


\section{RESEARCH DESIGN}

The study adopted a descriptive research design in collecting data from the respondents. Descriptive design portrays an accurate profile of persons, events, or account of the characteristics, for example behavior, opinions, abilities, beliefs, and knowledge of a particular individual, situation or group (Burns and Grove 2003). The descriptive research design was preferred because it ensured complete description of the situation, making sure that there is minimum bias in the collection of data (Kothari, 2003).From a target population of 189 in 7 Public schools in the District, stratified random sampling was used to obtain study sample of 95 teachers at 50\% sample ratio. Primary data was collected by use of questionnaires while secondary data was obtained from libraries, internet, reports from the District Education office as well as Ministry circulars, memos and other documentaries from the Ministry of Education. The questionnaire was tested for reliability using Cronbach's Alpha which measures the internal consistency. Nunnaly (1978) established the Alpha value threshold at 0.6 which the study benchmarked against. The values obtained was 0.81 which implied that the instrument was reliable and could be used to source for data. Descriptive statistics was used to analyze the demographic characteristics of the respondents, while correlation and regression statistics were used to analyze the study variables of ICT infrastructure, curricula, teacher readiness and adoption of elearning.

The regression model therefore was presented in the equation below:

$$
\mathrm{Y}=\alpha+\mathrm{b}_{1} \mathrm{X}_{1}+\mathrm{b}_{2} \mathrm{X}_{2}+\mathrm{b}_{3} \mathrm{X}_{3}+\varepsilon
$$

\section{DATA ANALYSIS AND INTERPRETATION}

A response rate of $86 \%$ was realized. Majority of whom (64\%) were female. In age distribution, $25.6 \%$ were 20-30 years; 31-40 years and 41-50 years represented $29.5 \%$ and $24.4 \%$ of the respondents respectively. Majority of the respondents (35.9\%) had diploma certificates, and majority (36\%) had been in the school for between 5 and 9 years.

Majority of the respondents (56\%) indicated that their school had adopted e- learning, while 44\% indicated that their school has not adopted e- learning which is tandem with the position of the Government of Kenya (2007) that E-learning in Kenya has been adopted and implemented across academic institutions

According to the respondents parents were the main supporters of the e-learning (35.9\%), followed by the school (28.2\%), donors $(19.2 \%)$ and private partnerships $(16.7 \%)$. This finding is consistent with the findings of infoDev; (2007) that had established that e-learning in most academic institutions is supported by non- governmental organizations. Sixty-six percent $(66 \%)$ of the respondents agreed that the schools had challenges with e-learning while $34.0 \%$ disagreed, a position consistent with the BECTA Report (2003).

Majority of the respondents (35.7\%), strongly agreed that the development of digital curriculum had enhanced the adoption of e-learning, 55.6\% strongly agreed that the rolling out of e-learning programs, with the support of private and public sector players, had enhanced e-learning while $40.1 \%$ agreed that e-learning had enhanced the enrollment of large number of learners. Another $50.0 \%$ of the respondents strongly agreed that the adoption of e learning has made education more affordable and accessible, increasing enrollments and improving course quality. Such findings confirms the report by the Government of Kenya (GoK, 2007) that the government is developing digital content material and that of Olakulehin(2008) that the increase in enrolment rates in a distance education system lowers the unit cost per learner

On the relationship between measures of adoption and adoption of e- learning in secondary schools in Kenya, indicates that there is a positive correlation coefficient (r) of .752 and the coefficient of determination $\left(\mathrm{r}^{2}\right)$ of .566 indicating that $56.6 \%$ of the successful adoption of e- learning can be explained by development of curriculum, rolled out e-learning programs, growth in student enrolment and affordability and accessibility of e- programmes.

Table1. Correlation Model

\begin{tabular}{|l|l|l|l|l|l|}
\hline Model & R & R Square & df & P-Value & Sig. \\
\hline 1 & $0.752^{\mathrm{a}}$ & $0.566^{\mathrm{a}}$ & 5 & $0.189^{\mathrm{a}}$ & $0.013^{\mathrm{a}}$ \\
\hline
\end{tabular}

a. Dependent Variable: Adoption of e-learning 
The findings of this study concur with the observations of Schrum and Ohler (2005) and Olakulehin, (2008) that distance education significantly challenges the standard onsite educational culture pedagogically, organizationally, technologically and financially and that the increase in enrolment rates in a distance education system lowers the unit cost per learner.

The role of infrastructure in the adoption of e- learning half of the respondents agreed that poor ICT infrastructure is barrier to e-learning adoption, $44.4 \%$ agreed that the low tele-density and high costs of installing and maintaining Internet connectivity is a major barrier, $61.1 \%$ agreed that the number of computers available is a barrier and another $73.7 \%$ agreed that the costs of installation and maintenance of ICT remain a challenge. These findings concur with the views expressed by Nwagwu and Ahanihe (2006), who noted that efforts to improve ICT access in Africa have been hampered by a shortage and high cost of equipment, software and information; the lack of reliable and accessible physical telecommunications infrastructure; telecommunications monopoly, associated with overly restrictive regulations and high costs. On whether ICT infrastructure influences the adoption of elearning in public schools in Kenya the majority of the respondents $(78.3 \%)$ agreed that ICT infrastructure influences the adoption of e-learning in public schools in Kenya, while $21.7 \%$ disagreed. Bigum, (2000) noted that low investment in ICT infrastructure coupled with high cost of connectivity and bandwidth affect the adoption of e-learning in schools, a concurrence with the study findings. They also citedtough financial situations which constrain their ability to pay for costly infrastructure, sustaining computer networks as the costs of installation, maintenance and expansion remain high.

The study also sought to find out the relationship between the E-learning Curricula and Design to which the majority $(41.7 \%),(52.8 \%),(44.4 \%)$ and $(36.1 \%)$ of the respondents agreed and strongly agreed respectively that: e- learning has not been fully integrated into their curricula; teachers are not fully aware of or familiar with e-learning content and outcomes; e-learning imposes a new learning method that teachers are required to embrace in order to ensure the success of e learning implementation and e-learning curricula are not designed in such a way that is relevant to needs of the learners' quality of delivery and learning approaches. This was a confirmation of the findings by Abouchedid and Eid (2004) who established that school administrators and teachers were not fully aware of or familiar with e-learning content and outcomes because of the drastic shift in the learning model and that there were no adequate plans designed to guide schools so as to ensure a smooth educational transition to e-learning

Majority of the respondents (76.9\%) agreed that e-learning curricula affects the adoption of e-learning in public schools, while $23.1 \%$ disagree that the adoption of e-learning in public schools in Kenya is affected by e-learning curricula, a finding which agrees with the observations of Pinheiro (2002) that e-curriculum is a connective link between teacher and student, organized in such a way to achieve goals set by the teacher and the school hence influence the adoption of e- learning in schools. Respondents indicated that there is lack of effort among school official to guide educational institutions for a smooth transition to e-learning and to design e learning curriculum to guide instructors on how to deliver information to students with respect to the amount of information and the time that will be required.

On the readiness of teachers to apply e-learning in their teaching, majority (83.3\%), (44.4\%), (72.2\%) and $(55.6 \%)$ of the respondents strongly agreed and agreed respectively that: teachers need to acquire necessary knowledge and skills that allows them to shift from traditional teaching experiences to an elearning teaching style; teachers who may not be technological literate resist the innovation of technology because of fear of losing their jobs if e-learning is implemented; teacher readiness of teaching with e-learning is important, because it can support the expansion e learning programme; providing supportive e-learning environments for teachers early on and can gradually build up elearning as an effective teaching method. Gray, Ryan and Coulon, (2004) and Levinsen (2007) had found out that successful design and management of e-learning courses require new skills and competencies among teachers to overcome major problems such as user needs analysis, instructional design, development of materials, delivery of information, and evaluation of the course. Traditional skills are essential to e-learning but are insufficient. From the study, $70.5 \%$ of the respondents agreed that teacher's readiness influences the adoption of e-learning in public schools, while $29.5 \%$ disagree that the adoption of e-learning in public schools is influenced by teacher's readiness. 


\section{Regression Model}

The model was analysed to find out the relationship between variables of the study. In using the regression model $\mathrm{Y}=\alpha+\mathrm{b} 1 \mathrm{X} 1+\mathrm{b} 2 \mathrm{X} 2+\mathrm{b} 3 \mathrm{X} 3+\varepsilon$, the study sought to determine whether the coefficients on the dependent variable (adoption of e-learning in secondary schools) is different from 0 so that the independent variable (technological infrastructure, e-learning curricula and teacher readiness) is having an effect on dependent variable (adoption of e-learning) or if alternatively any apparent differences from 0 is just due to random chance. Results indicate a positive correlation coefficient $(\mathrm{r})=0.793$, coefficient of determination $(\mathrm{r} 2)=0.629$ indicating $62.9 \%$ probability of adoption of e-learning is related to technological infrastructure, e-learning curricula and teacher readiness

Table2. Regression Model

\begin{tabular}{|c|c|c|c|c|c|c|}
\hline Model & $\mathrm{R}$ & R Square & $\mathrm{df}$ & \multirow{2}{*}{$\begin{array}{l}\text { P-Value } \\
0.227^{\mathrm{a}}\end{array}$} & \multirow{2}{*}{\multicolumn{2}{|c|}{\begin{tabular}{|l|l|} 
Sig. \\
$0.028^{\mathrm{a}}$
\end{tabular}}} \\
\hline 1 & $0.793^{\mathrm{a}}$ & 0.629 & 6 & & & \\
\hline \multicolumn{6}{|c|}{ a.Dependent Variable: Adoption of e- learning } & \\
\hline \multicolumn{7}{|c|}{ Table 4.22 Coefficients ${ }^{\mathrm{a}}$} \\
\hline & & B & Std. Error & Beta & $\mathrm{t}$ & Sig. \\
\hline \multicolumn{2}{|c|}{ (Constant) } & 1.419 & 0.230 & & 6.169 & 0.000 \\
\hline \multicolumn{2}{|c|}{ ICT infrastructure } & 1.146 & 0.097 & 0.089 & 0.476 & 0.037 \\
\hline \multirow{2}{*}{\multicolumn{2}{|c|}{$\begin{array}{l}\text { E-learning Curricula } \\
\text { Teacher Readiness }\end{array}$}} & 0.279 & 0.085 & 0.159 & 0.936 & 0.054 \\
\hline & & 1.060 & 0.081 & 0.125 & 0.736 & 0.035 \\
\hline
\end{tabular}

Thus the model $\mathbf{Y}=\boldsymbol{\alpha}+\mathbf{b}_{1} \mathbf{X}_{\mathbf{1}}+\mathbf{b}_{\mathbf{2}} \mathbf{X}_{\mathbf{2}}+\mathbf{b}_{\mathbf{3}} \mathbf{X}_{\mathbf{3}}+\boldsymbol{\varepsilon}$ can be re-written as thus:

Adoption of E-learning $=1.1419+1.146($ ICT Infrastructure $)+0.279($ E-Learning Curricula $)+1.060$ (Teacher Readiness)

Which is interpreted as thus:

i. E-learning will be adopted even if the independent variables are not present to a level of 1.1419

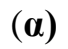

ii. When ICT infrastructure changes by 1 unit, e-learning adoption will increase by $1.146\left(\mathbf{b}_{\mathbf{1}}\right)$ which is a greater change than the unit change in the infrastructure

iii. When e-learning curricula changes by a unit (1), then adoption of e-learning increases by 0.279 $\left(\mathbf{b}_{2}\right)$ units, implying a minimal influence

iv. A unit change in the teacher readiness brings about $1.060\left(\mathbf{b}_{\mathbf{3}}\right)$ increases in the adoption of elearning. This is a significant influence by the readiness by the teachers to adopt the e-learning in schools

For the overall regression model, the computed $t$-value $(t=2.148)$ is less than the critical $t$-value $(\mathrm{t}=2.447)$ and the $\mathrm{p}$-value of 0.227 is larger than the significance level of 0.05 which implies that there is a significant relationship between technological (ICT) infrastructure, e-learning curricula, teacher readiness and adoption of e-learning in secondary schools. This is synonymous with the findings of Nwagwu and Ahanihe (2006), Abouchedid and Eid (2004) and Levinsen (2007) who established that low investment in ICT infrastructure coupled with high cost of connectivity and bandwidth are two major problems that face the development of ICT infrastructure and hence become barriers to elearning. E-learning course curricula may need to be designed in such a way that is relevant in the quality of information with the outside world because students will use different resources besides their instructor. E-learning course curricula may need to be based on learning approaches other than face-to-face course curriculum, which offers students opportunities to discuss their knowledge related to a certain topic rather than only to listen to the instructor as a provider of information. Teachers may need to acquire knowledge and skills in handling information and communication techniques for elearning courses.

\section{CONCLUSION AND RECOMMENDATIONS}

\subsection{Conclusion}

Secondary schools have low investment in ICT infrastructure due high costs of computer hardware, software and related accessories, coupled with high cost of connectivity and bandwidth, absence of 
electricity, lack of funding, low content development, insufficient building space, lack of available and trained staff, and poor security. Teachers are not fully familiar with e-learning content and outcomes, besides there is lack of effort among school official to guide educational institutions for a smooth adoption and implementation of e-learning and to design e learning curriculum to guide instructors on how to deliver information to students with respect to the amount of information and the time that will be required. The adoption of e-learning implementations has resulted in the need for development of new skills and competencies among teachers as most teachers who have been teaching in traditional manners are not technologically literate and sometimes may even resist because of the worry about losing their jobs ife-learning is implemented, because of their inadequate skills. Hence for successful adoption of e learning teachers require new kinds of skills, capabilities attitudes so as to successful use e-learning modules

\subsection{Recommendations}

i. There is need for schools to have e-learning infrastructure included in the budget lines to cater for maintenance and expansion of the ICT infrastructure and the acquisition and maintenance and training of teachers and technical staff. A cost sharing model can also be explored in which teachers are assisted to purchase computers through a recovery mechanism as this will facilitate computer acquisition in schools

ii. E-learning curricula may need to be designed in such a way that is relevant in the quality of information with the outside world because students will use different resources besides their instructor. E-learning course curricula may need to be based on learning approaches other than face-to-face course curriculum, which offers students opportunities to discuss their knowledge related to a certain topic rather than only to listen to the instructor as a provider of information.

iii. To ensure teacher readiness, teachers need to be equipped with new and relevant skills through re-training to adopt new skills and attitudes hence school official need to avail training opportunities to respective teachers so as to facilitate the effective adoption of e-learning in secondary schools

\section{REFERENCES}

Abdulsamad A (2005). "Rural School Sets Pace in IT". Daily Nation Newspaper pp 23 July 19th 2006 Nairobi: Nation Media.

Adam, L. (2003) Information and Communication Technologies in Higher Education in

Africa: Initiatives and Challenges, Journal of Higher Education in Africa. 1(1), 195-221.

Adomi, E. E. (2005), Internet Development and Connectivity in Nigeria Program: electronic library and information systems, 39(3), 257-268.

Aduke, A. F. (2008), Usage and Challenges of Information and Technology (ICT) in Teaching and Learning in Nigerian Universities: Asian Journal of Information Technology, 7(7), 290-295.

African Network of Scientific and Technology Institutions (2005), 'Action plan from the First African Regional Conference of Vice Chancellors, Provosts and Deans of Science, Engineering and Technology', UNESCO, Accra, Ghana 15-17, Nairobi

Ajadi, T. O., Salawu, I. O., \& Adeoye, F. A. (2008), E-learning and Distance Educationin Nigeria: The Turkish Online Journal of Educational Technology, 7(4), Article 7.

Amutabi, M. N. \& Oketch, M. O. (2003), 'Experimenting in distance education: the African Virtual University (AVU) and the paradox of the World Bank in Kenya': International Journal of Educational Development 23(1), 57-73.

Al-Doub, E., Goodwin, R. \& Al-Hunnaiyan, A. (2007), Students' Attitudes towards E-Learning in Kuwait's Higher Education Institutions, Published Ph.D Thesis

Allen MW (2003). Guide to e Learning: Building Interactive, Fun and Effective Learning Program for any Company. New Jersey: John Wiley and Sons.

Arikpo, I. I., Osofisan, A., \& Usoro, A. (2009), Bridging the digital divide: the Nigerianjourney so far. International Journal of Global Business, 2(1), 181-204.

Awoleye, M. O., Siyanbola, O. W., \& Oladipo, F. O. (2008), “Adoption assessment of Internet usage amongst undergraduates in Nigerian Universities" - a case study approach. Journal of Technology Management and Innovation, 3(1), 84-89. 
AJZEN, I. (1988). Attitudes, personality and behaviour. Milton Keynes: Open University Press.

Batchelor SE, Hearn S, Peirce S, Sugdem M, Webb SM (2003). ICT for Development: Contribution to the Millennium Development Goals. Washington: InforDev.

Batchelor S, Nocrish P (2005). Framework for Assessment of ICT Pilot Projects: Beyond Monitoring and $t$ Applied Research. Washington: InforDev.

Beebe, M.A. (2003), 'Partnerships, Alliances and Networks for e-Learning': In Africa dot edu. IT opportunities and higher education in Africa, Beebe et al. (Eds.) New Delhi: Tata McGraw Hill.

Beebe, M.A., Kouakou, K.M., Oyelaran-Oyeyinka, B. \& Rao, M. (2003) Africa dot edu. IT Opportunities and Higher Education in Africa. New Delhi: Tata McGraw-Hill.

Beebe, M.A. (2004). Impact of ICT Revolution on the African Academic Landscape

Dakar, Senegal.

Beatty, I. (2004). Transforming Student Learning with Classroom Communication Systems. Educause. Vol. 2. Issue 3

Birks, J., Hunt, F. \& Martin, J. (2007), Research into the use of information literacy web resources by Arabic Students. ZayedUniversity, UAE

Brennan, R. (2003). One size doesn't fit all, in Guthrie, H. (ed) (2003), "Online learning": research findings, NCVER and ANTA (55-68).

Bolaniran, A. \& Ademola, O. (2004), "E-Learning in Africa: related issues and matter arising" Proceedings of the 9th World Conference on Continuing Engineering Education, Tokyo.

Butcher, N. (2003) Technological infrastructure and use of ICT in education in Africa: An overview. Paris: Association for the Development of Education in Africa (ADEA).

Castells, M. (1998); The Information Age: economy, society and culture. Vol. III. End of the millennium. Malden, MA: Blackwell.

Clegg, S., Hudson, A. \& Steel, J. (2003), "The Emperor's New Clothes: globalization and e-learning in higher education". British Journal of Sociology of Education, 24(1), 39-53.

Coombs, N. (2000), 'Transcending distances and differences”. AAHE Bulletin, 53(2), 3-5.

Czerniewicz, L. (2001), 'Reflections on learning online - the hype and the reality': South African Journal of Higher Education, 15(3), 17-23.

Dutton, W.H. \& Loader, B.D. (2002), Digital Academe. The New Media and Institutions of Higher Education and Learning: London and New York: Routledge.

Findlow, S. (2006), Higher education and linguistic dualism in the Arab Gulf: British Journal of Sociology in Education, 27(1), 19-36.

Garrison, D.R. \& Anderson, T. (2003) e-Learning in the 21st Century: A framework for research and practice, London and New York: Routledge Falmer.

Gulati, S. (2008), Technology-Enhanced Learning in Developing Nations: A Review. International Review of Research in Open and Distance Learning, 9(1),

Hong, K.S., Ridzuan, A.A. \& Kuek, M-K (2003), Students' attitudes towards the use of the internet for learning: A study at a University in Malaysia. Educational Technology and Society Journal, Vol.6 Issue 2

Igwe, U. O. (2005), 'Harnessing Information Technology for the 21st Century': Library Education in Nigeria: Library Philosophy and Practice, 7(2).

Johnson, J.L. (2003), Distance Education: the complete guide to design, delivery and Improvement: New York: Teachers College Press.

Juma, M.N. (2003), 'The African Virtual University (AVU): Challenges and Prospects. In Africa dot edu' IT opportunities and higher education in Africa: Beebe et al. (Eds.) New Delhi: Tata McGraw Hill.

Kahiigi, E.K., Ekenberg, L., Hanson, H., Tusibira, F., Danielson, M. (2008). Exploringthe E-learning State of Art. Electronic Journal of E-Learning Vol.6, Issue 2.

Kenya Institute of Education (K.I.E) (2005). Information and Communication Technology Teaching Guide for Primary Teachers Training Colleges. Revised PTE Syllabus 2005. Nairobi: KIE 
Knowles, E. \& Kerkman, D. (2007);An Investigation of Students' Attitude and Motivation towards On-line Learning, Student Motivation, Vol. 2

Leary, J. \& Berge, Z. L. (2006), "Trends and challenges of e-Learning in national and international agricultural development": International Journal of Education and Development using ICT, 2(2).

Marsden, R. (1996), Time, Space and Distance Education Distance Education, 17(2), 222-246. McFall, J. A., \& Freddolino, P. P. (2000) The Impact of Distance Education Programs on Community Agencies. Research on Social Work Practice, 10(4), 438-453.

Marshall, S. \& Taylor, W. (2009), Editorial; Potential Challenges in the Use and Adoption of ICT, International Journal of Education and Development, Vol.5 Issue 3

Mooij, T. (2007), 'Design of educational and ICT conditions to integrate differences in learning: Contextual learning theory and a first transformation step in early education', Computers in Human Behavior 23(3), 1499--1530.

MOE (2006). National Information and Communication Technology (ICT) Strategy for Education and Training. Nairobi: Government Printers.

MOEST (2005). Kenya Education Sector Support Programme 2005 - 2010; Delivering Quality Education and Training to all Kenyans. Nairobi: Government Printers.

Mungania, P \& Reio, T.G. (2007), "If E-Learners get there, will they stay? The role of e-learning selfefficacy: Online Submission (2005) ERIC. 8 May

Nafukho, F. M. (2007), 'The Place of E-learning in Africa's Institutions of Higher Learning': Higher Education Policy, 20, 19-43.

Ndulu, B. J. (2004). Human Capital Flight: 'Stratification, Globalization, and the Challenges to Tertiary Education in Africa': Journal of Higher Education in Africa, 2(1), 57-91.

NEPAD e-Africa Commission (2003). The NEPAD e-Initiative: Ensuring that Young Participate Actively in the Global Information Society and Knowledge Economy. Nairobi, NEPAD

Noble, D.F. (2002) Digital Diploma Mills: The Automation of Higher Education, New York: Monthly Review Press

Nwuke, K. (2003) Higher education, economic growth, and information technology in Africa: Some challenges and issues. In Africa dot edu. IT opportunities and higher education in Africa: Beebe et al. (eds). New Delhi: Tata McGraw Hill.

Okuogo G (2006). "Bridging the Digital Divide: Options Available for the ICT Uptake in Kenya". ICT J.: Daily Nation Newspaper v November 6th Nairobi: Nation Media.

Omwenga, E., Waema, T., \& Wagacha, P. (June 2004), "A model for introducing and implementing e-learning for delivery of educational content within the African context": African Journal of Sciences and Technology 5(1) 35-48.

Olakulehin, F. K. (2008), Open and Distance Education as a Strategy for Human Capital Development in Nigeria: The Journal of Open and Distance Learning, 23(2), 123-130.

Oyeyinka, B. O., \& Adeya, C. N. (2004). Dynamics of Adoption and Usage of ICTs inAfrican Universities: A Study of Kenya and Nigeria. Technovation, 24, 841-851

Perraton, H. (2007a). Higher Education: Beyond the Courtyard Wall Open and Distance Learning in the Developing World (Second ed.): New York: Routledge.

Perraton, H. (2007b). Open and Distance Learning in the Developing World (2nd ed.). New york: Routledge.

Punie, Y., Zinnbauer, D and Cabrera, M. (2006), A Review of the Impact of ICT on Learning .Working Paper- European Commission

Rovai, A. P. (2003), 'A practical framework for evaluating online distance education programs', The Internet and Higher Education 6(2), 109-124

Sharma, R. (2003), 'Barriers in Using Technology for Education in Developing Countries', IEEE 07803-7724-9103

Saint, W., Hartnett, T., \& Strassner, E. (2003). Higher Education in Nigeria: A Status Report. Higher Education Policy, 16, 259-281.

Schoepp, K. (2005), Barriers to integration in a technology rich environment. Learning and Teaching in Higher Education: Gulf perspective, (2), 1-24. 
Determinants of E-Learning in Secondary Schools in Kenya: A Case of Selected Public Secondary Schools in Westlands District in Nairobi City County

Simmons, D.E. (2002). "The forum report: Elearning adoption rates and barriers": In A. Rossett (Ed.).The ASTD e-learning handbook: Best practices, strategies and case studies for an emerging field: New York: McGraw Hill.

Sharma, R., Ekundayo, M. S., \& Ng, E. (2009), Beyond the digital divide: policy analysis for knowledge societies: Journal of Knowledge Management, 13(5), 373-386.

Teferra, D., \& Altbach, P. G. (2004), African Higher Education: Challenges for the 21st Century. Higher Education, 47, 21-50.

UNESCO, (2002), 'Open and Distance Learning Trends, Policy and Strategy Considerations', Geneva, UNESCO,

Youssef, B.and Dahmini, M. (2008). The Impact of ICT on Student Performance in Higher Education: Direct Effects, Indirect Effects and Organisational Change. Published Ph.D Thesis

Valasidou, A. (2006). The Impact of ICTs in Education: The Case of University of Macedonia Students

\section{AUTHORS' BIOGRAPHY}

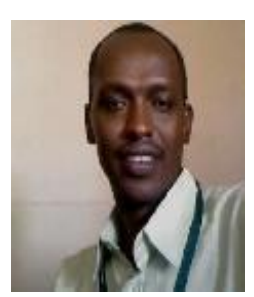

Francis K. Mutua, is an ICT officer /IT Consultant at Kenya National Examination Council. He persuing $\mathrm{PhD}$ (ongoing) in Business -Management of Information Systems option at Kenyatta University and completed MBA --Management of Information Systems option in Kenyatta University and BSc Computer science with London Metropolitan University

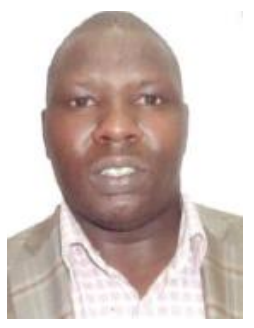

Weldon K Ng'eno, is a Lecturer in the Department of Public Policy and Administration at Kenyatta University. He persuing $\mathrm{PhD}$ (Ongoing) in Human Resources, and he completed MBA (Human Resources Management), Higher Diploma (HRM), and B.Ed (A) in Economics and Business Studies. He is an Associate Member of the Institute of Human Resources Management (IHRM). He has an Experience of 10 years in university teaching and ToT in Blackboard Learning Moodle Systems and published several publications in International relations and Human Resources 